\title{
"Emoção", "técnica", raiva e amor na aplicação da Lei do Feminicídio em um júri público no Rio de Janeiro
}

\author{
BRENA O'DWYER \\ Universidade Federal do Rio de Janeiro, Rio de Janeiro, Rio de Janeiro, Brasil
}

DOI 10.11606/issn.2316-9133.v28i2p198-216

resumo Este artigo resulta de uma pesquisa de doutorado em andamento. Seu objetivo é, a partir de uma etnografia de um júri público de feminicídio no Rio de Janeiro, ocorrido em 2019, analisar como diferentes noções de gênero e emoções permeiam os discursos tanto da defesa quanto da acusação do réu. Este trabalho visa contribuir com os estudos sobre violência contra a mulher com foco na análise do papel das emoções mobilizadas pelos atores envolvidos. O artigo discute o lugar das emoções no debate sobre violência e Estado, em oposição à ideia de que as emoções estariam presentes apenas na esfera privada (ou de que esta poderia ser separada da esfera pública). Procura também refletir sobre a mútua construção do gênero e do Estado e sobre o papel da violência nesse processo.

palavras-chave gênero, emoções, Estado, violência

"Emotion", "technique", angry and love" to apply the Feminicide Law in an audience at Rio de Janeiro

abstract This article is the result of ongoing doctoral research. Its purpose is, from the analyzes of a public jury of femicide in Rio de Janeiro, in 2019, to analyze how different notions of gender and emotions permeate the speeches of both the defendant's defense and the accusation. This paper aims to contribute to studies on violence against women focusing on the analysis of the role of emotions mobilized by the actors involved. The article discusses the place of emotions in the debate on violence and state, as opposed to the idea that emotions would be present only in the private sphere (or that it could be separated from the public sphere). It also seeks to reflect on the mutual construction of gender and state and the role of violence in this process.

keywords gender, emotions, State, violence 


\section{Introdução}

Este artigo resulta de uma pesquisa de doutorado em andamento ${ }^{1}$ e objetiva, a partir de uma etnografia de um júri público de feminicídio no Rio de Janeiro, analisar como diferentes noções de gênero e emoções permeiam os discursos tanto da defesa quanto da acusação.

Tradicionalmente, os júris populares decidem sobre crimes intencionais contra a vida - auxílio ou instigação ao suicídio, aborto, infanticídio e homicídio doloso, sendo o feminicídio uma nova qualificadora deste último. O júri é formado por sete jurados ${ }^{2}$, como representantes da sociedade civil, que decidem após ouvir a leitura do processo, as testemunhas, o réu e os argumentos do promotor público e da defensoria, nesta ordem. Os juízes, defensores públicos, ministério público (na figura do promotor público) e advogados organizam argumentos considerados apropriados, nestes argumentos determinados atributos de feminilidade e de masculinidade são apresentados para convencer os jurados de suas teses. Tanto a defesa quanto a acusação utilizam, por exemplo, o que chamam de "argumentos feministas" e rechaçam o que consideram argumentos "emocionais" em oposição aos "técnicos".

Assim, este trabalho procura dialogar com os estudos sobre violência contra a mulher tomando por foco suas análises do papel das emoções mobilizadas pelos atores envolvidos. A pesquisa visa contribuir para qualificar o lugar das emoções no debate sobre violência e estado, em oposição à ideia de que as emoções estariam presentes apenas na esfera privada (ou que esta pode ser separada da esfera pública como indicam COELHO; DURÃO, 2017). Tendo como plano de fundo a noção da mútua construção do gênero e do Estado e o papel da violência nesse processo (VIANNA; LOWENKRON, 2017).

Existem expectativas sociais sobre como as vítimas e os perpetradores devem se comportar nesses casos. Emoções específicas são mobilizadas na construção dessas duas figuras centrais para a judicialização dos conflitos, levando em consideração as expectativas sociais de gênero, sexualidade, classe, raça. O trabalho persegue as perguntas: Como as emoções são mobilizadas nos júris? Como essas emoções são articuladas e se constroem reciprocamente com noções de gênero nesse cenário?

$\mathrm{O}$ artigo analisa um júri de feminicídio que aconteceu na cidade do Rio de Janeiro no ano de 2019 que compõe parte do trabalho de campo de minha pesquisa de doutorado e está dividido em três sessões e considerações finais: a tipificação do feminicídio, na qual

\footnotetext{
${ }^{1}$ Resulta também em grande medida das disciplinas “Antropologia das Emoções”, ministrada pelas professoras Claudia Rezende e Maria Claudia Coelho no PPCIS/UERJ, e "Antropologia, Governamentalização do Estado e Colonialismo”, ministrada pelos professores Antonio Carlos de Souza Lima e Caio Gonçalves Dias no PPGAS/MN/UFRJ, ambas no primeiro semestre de 2019. Uma primeira versão deste trabalho foi apresentada no grupo de trabalho "Teorizar lo emotivo” da XIII RAM”. Agradeço aos colegas do GT e debatedores.

${ }^{2}$ Os júris são formados por vinte e um cidadãos intimados a comparecer ao tribunal e que devem ser alfabetizados, maiores de 21 anos e não ter antecedentes criminais. Sete desses vinte e um são sorteados e formam o conselho de sentença, os outros são dispensados. O serviço do júri é obrigatório.
} 
apresento o processo de criação da Lei em relação a outras leis sobre violência contra a mulher; o júri, na qual apresento um júri como caso etnográfico; o júri como efeito de estado, em que discuto o júri a partir da ideia de fazer estado (SOUZA LIMA, 2011); as emoções no júri, na qual penso a oposição entre técnica e emoção e, por fim, uma sessão com breves conclusões em que analiso como gênero e emoções se constroem mutuamente nesses contextos.

\section{A tipificação do Feminicídio}

A Lei do Feminicídio foi criada no Brasil em 2015. A partir dessa lei, o feminicídio passa a ser caracterizado como crime hediondo, definido como "por razões do sexo feminino”. No Brasil, a definição de violência contra a mulher foi elaborada em meio a uma prática na qual as militantes feministas atendiam mulheres que sofriam violência doméstica nos chamados SOS-Mulher nos anos 1980 (DEBERT; GREGORI, 1980). Em 1985 é criada a primeira Delegacia de Defesa da Mulher (DDM). A violência contra a mulher, contudo, não era então uma figura jurídica definida por lei, e a interpretação da situação dependia do agente penal. Assim, segundo Debert e Gregori (1980), nos anos 1980 o processo jurídico se dava em torno da queixa e a mulher precisava buscar acesso à justiça. Nos anos 1990, a "violência contra a mulher" é deslocada para a noção de "violência doméstica", sendo a "violência contra a mulher" expandida para outras categorias como crianças e idosos dentro do núcleo familiar.

Em 1995, com a criação dos Juizados Especiais Criminais (JECRIM), há uma mudança na forma como as DDMs conduziam as ocorrências. O objetivo da lei foi ampliar o acesso à justiça e promover a rápida atuação do direito, simplificando os procedimentos. Assim, os JECRIMs partiam do princípio da conciliação nos casos de crimes com menor poder ofensivo, isto é, crimes em que a pena não ultrapassasse dois anos. A maioria dos casos atendidos nas DDMs entram sob efeito dessa lei. Por exemplo, a lei permitia pagar penas alternativas como cestas básicas, sendo esta modalidade a pena imputada em caso de violência doméstica. Assim, os movimentos feministas passam a reivindicar mudanças que vão levar à promulgação da Lei Maria da Penha em 2006.

Ainda segundo o histórico apresentado pelas autoras (2008), a Lei Maria da Penha modificou esse cenário, com a criação de uma nova figura jurídica: a "violência doméstica e familiar contra a mulher”. A lei será posteriormente criticada por não incluir violência sexual ou assédio sexual, além de subsumir a violência de gênero ao espaço doméstico e à esfera familiar (2008, p. 172).

A partir desta perspectiva, a violência aparece como um problema social produzido em grande medida pelo movimento feminista desde os anos 1970 (VIEIRA, 2011, p. 13). Assim como a violência, as leis sobre sexualidade também foram alvo de modificações. Vieira (2011) chama atenção para as mudanças nos códigos penais envolvendo a sexualidade: 
Os crimes sexuais passaram por diversas definições no sistema judiciário ao longo do regime republicano, expressas nos Códigos Penais de 1890 e 1940, esse último ainda em vigor. Entre os tipos penais envolvendo a sexualidade no primeiro Código Penal estavam o defloramento, o estupro e o atentado ao pudor, entre outros. Já no segundo, o defloramento fora substituído pelo crime de sedução, permanecendo as demais tipificações. No Código de 1890, os crimes sexuais foram reunidos sob o título dos crimes contra a segurança da honra e honestidade das famílias e do ultraje público ao pudor e, no Código de 1940, sob o título dos crimes contra os costumes, no capítulo dos crimes contra a liberdade sexual. A classificação como crime relativo aos costumes passou a ser problematizada, a partir de fins dos anos 1980, por entidades feministas que iniciaram uma luta no campo jurídico para a inclusão dos crimes sexuais no capítulo dos crimes contra a pessoa, demarcando, assim, um espaço discursivo em defesa dos direitos individuais das mulheres. (VIEIRA, 2011, p.104-5)

Assim, a autora interpreta dois momentos sobre a noção de violência sexual: até o início do século XX e a partir dos anos 1970 com o "feminismo de direitos", isto é, ao definir a violência contra as mulheres como violência sexual o movimento feminista contribui para o entendimento da violência como parte da dimensão dos direitos individuais.

No primeiro Código Penal da República, de 1890 a 1940, os crimes sexuais mais comuns eram o estupro e o defloramento, sendo o primeiro necessariamente marcado pela violência no ato e o segundo usado para classificar a sedução de meninas menores de idade. No entanto, o debate principal era sobre a conduta, a virgindade e a honestidade das mulheres. A violência raramente aparecia como dado significativo nas narrativas dos processos de crimes sexuais. No caso do crime de defloramento muitas vezes o consentimento estava baseado na promessa de casamento: se esta não fosse cumprida, era considerado fraude. Nessas leis, a proteção da mulher ocorre a partir de seu lugar na família, como esposa e mãe, que corporificava a honra familiar (VIEIRA, 2011).

A partir dos anos 1990 surgem noções jurídicas ligadas aos chamados "direitos humanos das mulheres", especialmente a partir da conferência de Viena da ONU de 1993, referentes a uma tendência no campo dos direitos humanos de uma especificação dos sujeitos, especialmente aqueles compreendidos como minoritários. A partir dos anos 1990, a violência sexual passa a constar nos instrumentos internacionais de proteção aos direitos das mulheres (VIANNA; LACERDA, 2004 apud VIEIRA, 2011). Em 1994, é organizada a Convenção Interamericana para Prevenir, Punir e Erradicar a Violência contra a Mulher (Organização dos Estados Americanos). Também conhecida por Convenção de Belém do Pará, define a violência contra a mulher "como qualquer ação ou conduta, baseada no gênero, que cause morte, dano ou sofrimento físico, sexual ou psicológico à mulher, tanto no âmbito público como no privado".

Os códigos penais latino-americanos vêm se transformando. Nesse processo a figura da honra perde importância ao passo que a defesa dos direitos das mulheres ganha 
protagonismo, graças à pressão do movimento feminista nacional. A Lei Maria da Penha, de 2006, é um marco nesse processo e com a Lei do Feminicídio a emoção passional não é mais utilizada como argumento para eximir réus, como apontavam trabalhos anteriores como Jimeno (2004) e Côrrea (1983), ainda que apareça nos argumentos das defesas como justificativa ou atenuante.

A popularização da categoria "feminicídio" na América Latina se deu a partir da sua utilização na Cidade de Juárez, México, para caracterizar o contexto do desaparecimento e assassinato de centenas de mulheres ocorridos desde o início dos anos 1990 (IZUMINO, 2011; FRAGOSO, 2000 apud POSSES; OLIVEIRA 2016; JIMENO, 2004).

Pode-se dizer que há, atualmente, uma 'onda de tipificação' do feminicídio na América Latina: no ano de 2011, apenas cinco países da região possuíam leis versando sobre o feminicídio; atualmente, são quinze países. Contribui para esse cenário o recente posicionamento da ONU, que recomendou expressamente os países membros a reforçarem a legislação nacional para punir assassinatos de mulheres relacionados ao gênero, nas Conclusões Acordadas da 57a Sessão da Comissão sobre o Status da Mulher da ONU, de 2013. Foi a primeira vez que o termo feminicídio apareceu em um documento internacional acordado. (POSSES; OLIVEIRA, 2016, p. 16)

No Brasil, a lei definiu o feminicídio como um novo tipo penal, um tipo de homicídio qualificado praticado contra a mulher "por razões da condição de sexo feminino". Por ser um homicídio qualificado, há um aumento de pena em relação ao homicídio comum. Posses e Oliveira (2016) descrevem como na própria justificativa do projeto de lei aparece a ideia de continuum de violência apresentada por Russell e Radford no clássico livro Femicide: the politics of woman killing (1972). A lei é apresentada como parte da luta pela igualdade de gênero e universalização dos direitos humanos com a participação dos movimentos feministas, e como continuação na trajetória de combate à impunidade a violência contra a mulher, sendo a Lei Maria da Penha marco de referência. A criação de um tipo penal específico é argumentada a partir do reconhecimento que as mulheres são mortas por serem mulheres, expondo a desigualdade de gênero e o combate a impunidade.

Carmen Campos (2015) reconhece a proposta de criminalização do feminicídio no Brasil como parte de uma tendência na América Latina, desde os anos 1990, de reconhecer a violência contra as mulheres em suas especificidades. Trata-se de uma demanda feminista originada na verificação de que a violência de gênero era em geral ignorada pelo direito penal e naturalizada na sociedade, impedindo que as mulheres fossem sujeitos de direitos como preveem os direitos humanos. A autora compreende que as leis de feminicídio na América Latina fazem parte de uma segunda geração, posterior às leis que tipificam violência doméstica e familiar, como a Lei Maria da Penha no Brasil de 2006. 
A categoria femicídio/feminicídio é oriunda da teoria feminista. O termo femicídio (femicide) é atribuído a Diana Russell, que em 1976 o utilizou para referir a morte de mulheres por homens pelo fato de serem mulheres como uma alternativa feminista ao termo homicídio que invisibiliza aquele crime letal. Portanto, inicialmente o termo foi concebido como um contraponto à neutralidade do termo homicídio. Posteriormente, é redefinido por Jane Caputti e Diana Russell (1990) como o fim extremo de um continuum de terror contra as mulheres que inclui uma variedade de abusos físicos e psicológicos, tais como o estupro, a tortura, a escravidão sexual (particularmente a prostituição), o incesto, o abuso sexual contra crianças, agressão física e sexual, operações ginecológicas desnecessárias, assédio sexual, mutilação genital, heterossexualidade forçada, esterilização forçada, maternidade forçada (pela criminalização do aborto), cirurgia cosmética e outras cirurgias em nome da beleza. Qualquer dessas formas de terrorismo que resultem em morte será femicídio. O femicídio aparece então, como o extremo de um padrão sistemático de violência, universal e estrutural, fundamentado no poder patriarcal das sociedades ocidentais (CAMPOS, 2015, p.105).

Campos (2015) destaca que o femicídio/feminicídio está tipificado nas legislações da Argentina (2012), Bolívia (2013), Chile (2010), Colômbia (2008), Costa Rica (2007), El Salvador (2010), Equador (2014), Honduras (2013), Guatemala (2008), México (2012), Nicarágua (2012), Panamá (2013), Peru (2013) e Venezuela (2014). Afirma também que as legislações da região "definem como femicídio ou feminicídio as mortes de mulheres pelo fato de ser mulher, por razões de gênero, pela condição de mulher, por motivo de ódio ou menosprezo pela condição de ser mulher" (CAMPOS, 2015).

Por fim, na Câmara dos Deputados, segundo Campos (2015), a expressão "razões de gênero" foi substituída por "razões de condição de sexo feminino" e nesta nova redação a lei 13.104/2015 é aprovada, sendo as condições de sexo feminino definidas quando o crime envolve violência doméstica e familiar ou menosprezo ou discriminação à condição de sexo feminino. É importante destacar que a definição final da lei faz uma relação entre as mortes e o espaço doméstico e familiar, implicando uma linearidade com a Lei Maria da Penha que não tipificava o homicídio.

Campos (2015) esclarece que o nome jurídico reconhece uma violência específica, mas do ponto de vista criminológico a lei pode ser questionada uma vez que a morte de mulheres já é considerada uma violação aos direitos humanos, sendo também qualificada como homicídio: a lei foi criticada justamente pelo aumento da pena. A principio, a CPMI justificou o aumento da pena como proposta de visibilidade, mas segundo a autora existem outras formas de dar visibilidade ao feminicídio sem incrementar o poder punitivo. A autora indica, contudo, que a criação da lei pode impedir que os assassinatos sejam justificados como "crimes passionais" e que isso dê imputabilidade aos réus. 


\section{O júri}

Os júris públicos ocorrem quando há crime intencional contra a vida. Eles acontecem em uma ordem pré-determinada de falas, de forma rotinizada. Há um juiz, um representante do Ministério Público (MP) na figura do promotor público que preside a acusação ao réu ${ }^{3}$, um representante da Defensoria Pública (DP) que faz a defesa e sete jurados que votam a decisão ao final em uma sala secreta. No início de cada júri o juiz sorteia os jurados. Eles fazem um juramento e, depois disso, o juiz lê a sentença. Após a leitura, se houver testemunhas, elas são interrogadas pelos MP e DP. O réu tem direito a falar ou permanecer em silêncio. O MP profere seus argumentos seguido da DP. Toda essa parte do júri é pública e pode ser acompanhada pela plateia, diferentemente do momento em que os jurados votam, o qual a plateia não pode assistir. Tendo os jurados chegado a um veredito, a plateia pode retornar à sala e o juiz lê o veredicto, estipula a pena e encerra o julgamento.

Narro a seguir um júri de feminicídio a que assisti em finais de maio de 2019 no TJRJ. A juíza, a representante da Defensoria Pública e a representante do Ministério Público são mulheres. O réu se chama Josué, tem 45 anos, auxiliar de padaria. As vítimas são Michele, 40 anos, autônoma, e sua filha Lorraine, 18 anos, estudante. Depois de sortear os jurados a juíza lê a acusação. Em agosto de 2017, no bairro do Catumbi, Rio de Janeiro, o denunciado "com vontade de matar" esfaqueou Michele; o crime não se consumou porque a vítima recebeu apoio médico. O motivo do crime é "fútil" em decorrência do término do relacionamento e "cruel" pelo ataque ter sido feito pelas costas. Consta também "motivo de sexo feminino" por ter ocorrido no âmbito da violência doméstica, visto que eram ex companheiros e moravam juntos. Portanto, a própria definição do crime, como descrito anteriormente, aponta para a centralidade do relacionamento amoroso nas definições legais de violência contra a mulher. No caso de Lorraine o motivo também é "fútil”, com crueldade e por "razões do sexo feminino", visto que ela é filha de Michele e residiam juntos à época dos fatos. "Fútil" e "cruel" aqui são categorias êmicas com definições legais específicas: o motivo fútil é aquele considerado insignificante ou desproporcional e o motivo torpe quando executado com emprego de veneno, fogo, asfixia, explosivo ou meio cruel, ambas circunstâncias agravantes que determinam maior gravidade da culpabilidade. A MP e a DP explicam essas categorias jurídicas em seus argumentos para os jurados.

A vítima é chamada para testemunhar. A representante do Ministério Público pede a Michele que conte o que aconteceu no dia. Ela conta que eles foram casados por catorze anos e têm uma filha de oito anos. No dia do ocorrido já estavam separados, mas segundo Michele, tinham uma boa relação por conta da filha; ele sempre pagara a pensão em dia e em mãos. Alguns meses antes eles teriam se encontrado por conta da pensão e ela percebeu que ele estava muito doente e debilitado. Haviam ido juntos a uma Unidade de Pronto

\footnotetext{
${ }^{3} \mathrm{O}$ papel do promotor é de defender o interesse da sociedade, assim, se ele percebe que o réu é inocente ou que merece determinado tratamento em vistas das circunstâncias do crime ele deve pedir a absolvição ou pena aplicável. Isto ocorre neste júri quando a MP concorda com a DP sobre a figura da desistência voluntária, como será apresentado a seguir.
} 
Atendimento (UPA) e Josué fora diagnosticado com tuberculose. Depois foram à Clínica da Família, o diagnóstico foi confirmado e a Agente Comunitária lhe disse que ele precisaria morar próximo à Clínica para fazer o tratamento. Como eles tinham uma boa relação, Michele convidara Josué a morar com ela durante seis meses para fazer o tratamento. Michele diz que nesse momento eles não retomaram a relação e que o motivo do término foi que Josué "era muito mulherengo e eu não aguentava aquilo". Ela relata que ele tinha o próprio quarto e que nesse período eles não dormiam juntos.

Michele narra que na noite anterior Josué tentou manter relações sexuais com ela e ela não recusou. No dia seguinte, quando acordaram, ela pediu que ele fosse embora já que o tratamento estava no fim. Nesse momento, Michele chora enquanto conta o que aconteceu. Ela diz que nunca imaginou que aquilo pudesse ocorrer porque sempre tiveram uma boa relação, ainda que quando estivessem juntos ele fosse mulherengo, gostasse muito de festas e tivesse ciúmes dela. Conta que ele saiu de perto dela e ela se virou para a pia da cozinha para terminar de fazer o café quando sentiu um golpe na cabeça. Quando ela se virou de frente, ele enfiou a faca em seu peito e eles dois começaram uma luta corporal enquanto ela gritava. Ela diz que não se lembra como, mas conseguiu sair da cozinha quando sua filha mais velha saiu do quarto. Josué viu Lorraine sair do quarto, "partiu pra cima dela e a esfaqueou também”. Nesse interim a filha mais nova do casal, Natália, acordou e viu tudo da porta do quarto. Michele conseguiu ir até o portão da casa, quando Josué largou a faca e fugiu. Michele relata a pedido do Ministério Público que levou treze facadas, teve três órgãos perfurados; sua filha levou sete facadas e ficou também com uma deficiência na mão porque teve os tendões cortados ao tentar se defender.

A representante do Ministério Público (MP) pergunta a Michele como era o casamento dos dois. Michele relata que ela o amava muito, mas que ele bebia, era mulherengo e farrista. Ela narra que quando iam a festas juntos ele sentia muitos ciúmes dela. Ela diz que aprendeu a se amar e o deixou, mas que mantiveram contato por conta da filha e que ele sempre fora um bom pai. Ela diz que depois desse dia nunca mais se falaram. A MP pergunta como ficou Natália, a filha do casal, depois do ocorrido. Michele relata que Natália sempre fora uma criança doce, mas que agora está arredia e que conta para as colegas da escola que não tem pai. A MP não tem mais perguntas e a juíza passa a palavra para a Defensoria Pública.

A defensora pergunta de quem era a faca e onde ela ficava na casa. Michele responde que era uma faca de churrasco e que ficava guardada no armário. A defesa pergunta quem levou Michele ao hospital e ela responde que foram os vizinhos, que um vizinho era socorrista e fizera os primeiros socorros nela e na filha. A defesa pergunta se ele largou a faca sozinho, se poderia ter continuado a ataca-la e à filha; ela responde que sim, que Josué largou a faca quando ela abriu o portão.

Lorraine também testemunha. A MP pede que ela relate o que vivenciou no dia. Ela narra que estava dormindo e acordou com os gritos da mãe, que saiu do quarto e viu Josué com a faca atrás de Michele, que ela também começou a gritar e ele foi para cima dela. Nesse 
momento Natália saiu para o corredor, Josué viu que Michele tinha chegado ao portão e correu naquele direção, Lorraine então começou a gritar pelos vizinhos na janela da casa. Ela diz que perdeu o movimento de dois dedos. Ela narra que ele foi morar com elas porque estava com tuberculose. Lorraine relata que quando eles eram casados Josué era muito festeiro, às vezes passava noites fora de casa e ela não gostava da forma como ele tratava sua mãe. A defesa não tem perguntas a Lorraine, o acusado permanece em silêncio ${ }^{4}$ e a juíza inicia os debates.

A representante do Ministério Público começa sua fala elogiando a juíza ${ }^{5}$ por seu afinco e vontade de justiça, cumprimenta também a defensora pública, os Policias Militares e os jurados, diz que "aqui é a melhor Vara, o tribunal das mulheres". Volta-se para o júri e continua: "muitas vezes sentimos raiva aqui com os processos, mas temos que ser profissionais e afastar nossas emoções”. Diz que hoje Josué é imputado de duas tentativas de homicídio, Michele e Lorraine. Argumenta que não há dúvidas sobre o que ocorreu, que ele integrou a família delas e, mesmo quando não fazia mais parte, foi acolhido em momento de doença. Porém, isso não o impediu de praticar uma barbaridade. Impelido pela recusa de Michele, perdeu a cabeça e cometeu essa barbaridade. A MP pergunta retoricamente: "O que faz um homem ter esse comportamento? Ele, ex-marido, ex-padrasto, pai, acolhido naquela casa. Um comportamento que causa dor, cicatrizes físicas, emocionais e psicológicas eternas nas três". A MP continua:

Por mais que seja meu trabalho diário, eu não endureço aqui no júri, eu me sensibilizo. O que faz alguém praticar isso? Eu sou um ser humano, sou mulher, filha, esposa e tenho raiva desse homem que causou tanta dor, na frente da própria filha. Eu sou promotora de justiça, mas tenho raiva e desprezo como cidadã, pessoa, esposa e mulher. Mas devo buscar justiça como profissional, como técnica e não posso buscar tecnicamente de vossas excelências do júri a tentativa de homicídio, mas uma figura com uma pena menor. A desistência voluntária 6 .

A MP explica para os jurados que as mortes não se consumaram naquele dia porque ele largou a faca, que não foram circunstâncias alheias, ninguém o segurou, a faca não quebrou, a polícia não chegou a tempo. Ela explica que Michele e Lorraine narram a desistência dele, o momento que ele larga a faca e vai embora. Ela segue: "Não posso dizer que ele não tenha tido o intuito de matar, visto a faca e a quantidade de facadas em cada uma que indicam a intenção de matar. Até porque ele não foi pra cima da própria filha. Mas ele

\footnotetext{
${ }^{4} \mathrm{O}$ réu tem direito de permanecer em silêncio sem que isso tenha prejuízo para ele, os jurados não devem considerar o silêncio no sentido de "quem cala consente", pois é seu direito constitucional.

${ }^{5}$ Em todos os júris a que assisti o Ministério Público e Defensoria Pública sempre começam suas falas cumprimentando um ao outro, o juiz, jurados, policiais militares e etc.

${ }^{6}$ Acontece quando o agente começa a praticar os atos punidos penalmente, mas voluntariamente interrompe sua conduta.
} 
efetivamente não matou elas e não foi por impedimento externo, ele desistiu”. A MP continua seu argumento:

Hoje, eu preciso separar o lado humano e pedir o técnico, não como ser humano, como cidadã não quero que ele volte a integrar a nossa sociedade. Mas como Ministério Público só posso pedir o técnico. Tenho certeza que essas mulheres nunca vão esquecer isso, mas a justiça que o processo permite buscar é essa. Embora tenha iniciado os atos ele voluntariamente desistiu de prosseguir. Hoje o Ministério Público pede pela desclassificação da conduta. Vossas excelências reconhecendo a desistência voluntária, a juíza fará a justiça.

A Defensora Pública (DP) começa sua fala também cumprimentando a juíza, diz que é uma satisfação trabalhar com uma pessoa serena e competente. Cumprimenta também a MP, já trabalham juntas há muito tempo, e têm laços de amizade e profissionalismo. Diz ao senhor Josué que nessa tarde, ainda que ela esteja com o coração amargurado, espera que ele tire uma lição de vida daqui. Por fim, cumprimenta os jurados.

Ela argumenta que a realidade desse processo é triste, trágica e chocante, que é o que hoje é chamado de feminicídio, "algo que não sei se está mais comum ou se as mulheres estão denunciando, mas está sendo mais noticiado”. A DP prossegue e chama o feminicídio de barbárie, de algo da idade da pedra. Ela diz que a autoria é inconteste, foi ele quem realizou as facadas, relata que conversou com ele e que ele se diz arrependido por ter cedido à raiva do momento. Contudo, continua a DP, esse comportamento é inadmissível. Ela concorda com o argumento da MP, de que houve a desistência voluntária, dizendo que o tribunal é o lugar da justiça e não da vingança e por mais que tenham raiva dele como pessoa, precisam julgar pelo que ocorreu, pelos fatos e não pelas emoções. E que no caso houve a desistência voluntária, que ele deve responder pelos atos praticados, as lesões corporais gravíssimas, com todas as qualificadoras; doméstica, motivo fútil, crueldade, na frente de menor; mas não a homicídio.

A materialidade e autoria existiram, e esses são os dois primeiros quesitos que peço que os senhores jurados respondam sim. Peço que respondam sim também para o terceiro quesito qualificando como desistência voluntária. Não é uma desclassificação, é outra tese, é uma questão doutrinária, mas a consequência é a mesma, quem vai julgar e mensurar a pena vai ser a juíza.

Nesse momento, a defensora se vira para Josué e fala com ele: "espero que você tenha aprendido que isso é inaceitável, você não está dando exemplo pra sua filha. Se você levantar a mão pra qualquer pessoa de novo você vai pra cadeia. Espero que você veja isso como uma bênção de Deus na sua vida, te dando uma nova chance. Espero que você aprenda isso”. Ela se volta novamente para os jurados, repete os três quesitos e insiste na desistência voluntária. 
$\mathrm{Na}$ sentença ${ }^{7}$ os jurados atestam os argumentos da MP e DP e votam pela desclassificação da conduta de tentativa de homicídio para lesão corporal gravíssima por duas vezes, tendo Michele e Lorraine como vítimas. O motivo fútil pelo término do relacionamento é confirmado na sentença assim como "o acusado praticou o crime com violência contra a mulher, por razões da condição do sexo feminino”.

\section{O júri como efeito de estado}

É possível pensar os júris a partir de uma bibliografia que tem se convencionado chamar antropologia do estado e indica a valorização das atualizações cotidianas do estado em diversas ações estereotipadas e rotinizadas, na ideia de fazer Estado (SOUZA LIMA, 2012). Esses autores permitem uma visão multifacetada e pluricentrada do estado, para entender sob quais condições o estado consegue com sucesso representar a si mesmo como coerente e singular. Os júris seguem sempre uma determinada ordem: o sorteio dos jurados, o juramento, a leitura do processo, o interrogatório das testemunhas, a fala do réu (ou seu silêncio), o argumento do Ministério Público, a Defensoria e por fim a votação dos jurados que se materializa posteriormente na sentença.

Assim, nesses espaços a administração pública e o direito têm um sentido de representação e performance, além de um cotidiano de relações sociais presente, por exemplo, nos elogios trocados entre Ministério Público e Defensoria Pública. Portanto, a análise dos júris nesse sentido pode ajudar "a reconhecer e a ultrapassar de uma vez por todas a idéia de 'O Estado' - e este 'O Estado' é o Estado (mono)nacional - enquanto entidade existente que se instala inexoravelmente quando se declara que está criado um Estado nacional baseado no modelo liberal burguês democrata" (SOUZA LIMA, 2012, p. 38).

Abrams (2006) argumenta que o Estado se produz em atos cotidianos burocráticos e institucionais, naquilo que o autor chamou de Estado-sistema, e também na ilusão de homogeneidade constituinte do próprio Estado que seria o Estado-ideia. Os júris são espaços que revelam essa dupla característica do Estado: tanto seus processos de construção diários e rotinizados, quanto sua ideia como ente que se produz, por exemplo, na materialidade da sentença, mas também no juramento dos jurados; sendo o Estado-sistema e o Estado-ideia duas partes do mesmo processo. Mitchell (2006) retoma os argumentos de Abrams e entende que a aparência do Estado como instituição social autônoma é feita através de reificações no dia a dia de práticas sociais (MITCHELL, 2006), como nos júris. Assim, os autores salientam a importância de pensar o Estado em suas práticas, de forma processual e em permanente construção. $\mathrm{O}$ autor também indica a importância de apreender o estado como um efeito de processos mundanos que criam a ilusão de um mundo fundamentalmente dividido entre estado e sociedade.

Mitchell (2006) chama atenção para a lei como componente central do Estado quando concebido em termos estruturais ou como sistema. O autor argumenta que na

\footnotetext{
${ }^{7}$ A sentença fica disponível no site do TJRJ, a consulta é feita com o número do processo que pode ser obtido no cartório, no mesmo andar dos júris.
} 
prática tendemos a simplificar a distinção da lei como um código abstrato e a sociedade como seu campo de atuação. Contudo, segundo o autor, muitas vezes o código e a prática são inseparáveis (2006, p. 176). Neste júri isso aparece precisamente na parte da argumentação quando MP e DP pedem que os jurados deixem de lado suas emoções para votar por uma sentença "justa e técnica” com a figura da desistência voluntária.

Sharma e Gupta (2006) pensam o estado a partir das práticas diárias e de suas representações. No júri o estado é encenado nas figuras do juiz, MP, DP e jurados, assim como nas leis. Essa perspectiva processualista ajuda a compreender como a ambiguidade da interpretação das leis e mesmo argumentos diferentes do MP e DP se manifestam simultaneamente nessa representação. Os autores (2006) chamam atenção também para a constituição cultural do Estado, isto é, como ele é percebido pelas pessoas, como esses entendimentos são construídos em locais particulares, como se manifestam nesses locais, qual o significado dado pelas pessoas e como é experienciado no cotidiano. Da mesma forma, o júri é reificado como local legitimado da justiça não só no código penal e nas falas da promotora e defensora, mas na noção de que a sociedade através dos jurados decide a sentença. $\mathrm{O}$ estado se reproduz nessas atividades mundanas e nessas rotinas diárias. As desigualdades sociais, de classe e gênero, por exemplo, são produzidas e mantidas.

O estado se produz nos júris através dos argumentos do Ministério Público e Defensoria, nos jurados e na sentença final, produzindo um efeito de unicidade a partir dos argumentos - muitas vezes contrastantes - do MP e DP. Assim, a ideia, apontada pelos autores como parte do fenômeno do Estado, de que sociedade e Estado estão separados é resolvida no júri através das figuras dos jurados como representantes da sociedade, que em casos de crime contra a vida devem decidir a sentença, mas são guiados pelo Ministério Público e Defensoria a considerar principalmente as figuras jurídicas culminando na sentença, que pode ser pensada como efeito de Estado.

\section{As emoções no júri}

As emoções são apresentadas nos júris como motivo torpe para a morte marcadamente o ciúme nos casos de feminicídio - e no caso apresentado aparecem como algo a ser desqualificado pelos jurados ao decidirem pela sentença, tanto na fala da MP quanto da DP. A raiva é apresentada pela DP como algo que toma o réu, mas nem por isso justifica seu crime e, ao mesmo tempo, como sentimento compreensível por parte dos jurados em relação ao réu. Ainda que a raiva seja um sentimento apropriado, ela deve ser "deixada de lado" para que os jurados possam tomar o que tanto MP quanto DP chamam de uma decisão "técnica", isto é, nas suas falas, oposta ao que seria uma decisão "emocional".

Norbert Elias (1994) demonstrou a conexão entre a ideia de civilização e um maior controle emocional, relacionando a transformação da sociedade à transformação do tipo de personalidade dos indivíduos na mesma. O autor (1994) explica que nas sociedades de pequena escala a violência era necessária e não havia muito controle das emoções, a agressividade era valorizada e as pessoas eram pouco reflexivas. Nesse contexto, havia a 
tendência ao monopólio da violência: nas sociedades estudadas por Elias (1994), as unidades foram se juntando e constituindo unidades políticas cada vez maiores. Conforme as unidades foram aumentando, o inimigo se distanciando, o que permitiu uma maior diferenciação entre as pessoas. Nessa configuração era melhor para a pessoa ser autocontrolada, reflexiva. Assim, segundo o autor, os níveis de pudor aumentaram e as emoções passam a precisar de controle.

No clássico A expressão obrigatória dos sentimentos (1980) Marcel Mauss aponta, a partir de rituais funerários, que as expressões emocionais, inclusive aquelas tomadas como mais espontâneas, como as lágrimas funerárias, são na verdade coletivas e obrigatórias. $\mathrm{O}$ autor indica que as emoções são sociais e ritualizadas e que existem maneiras apropriadas de expressá-las e de não as expressar. Neste júri podemos ver como a raiva é apresentada como uma reação compreensível dos jurados em relação ao réu, mas que não deveria ter lugar em seu desempenho como jurados, apresentado como o espaço da técnica, que seria oposta à emoção. Assim, por mais que tanto MP quanto DP apresentem a decisão final como "técnica", há uma oposição entre o que seria técnico e o que seria emocional justamente na ideia de que seria preciso "colocar a raiva de lado". Isso pode ser exemplificado no momento quando a Promotora diz: "eu tenho raiva desse homem que causa tanta dor... Mas devo buscar a justiça como profissional, como técnica”. Assim a MP sinaliza uma separação entre o que seria privado, sua raiva, sua posição como esposa e pessoa, e o que seria público, sua profissão e a técnica. A expressão dos sentimentos é obrigatória como cidadã ou como mulher frente ao feminicídio, como ela comenta, mas deve ser afastada no fazer justiça. Assim, a justiça apesar de não ser livre de emoções não pode ser conduzida por elas. A raiva é legítima e pode ser expressa no discurso, mas não pode orientar as condutas, seja das profissionais seja dos jurados. Podemos pensar inclusive que a fala controlada sobre suas emoções faz parte da construção de seu profissionalismo, elas combinam o fato de se sentirem afetadas pelo ocorrido (como humanas, cidadãs) com um trabalho emocional (HOSCHILD, 2013) no sentido de fazerem um trabalho profissional, sério e qualificado.

Da mesma forma, Lutz e Abu-Lughod (1990) argumentam que a dicotomia entre razão e emoção, assim como o entendimento das emoções como interiores e alocadas no corpo natural, fazem parte do discurso do senso comum no Ocidente moderno. As autoras apresentam quatro estratégias utilizadas pela antropologia para pensar as emoções: essencializar, relativizar, historicizar e contextualizar o discurso emotivo. Brevemente, elas indicam que na primeira estratégia as emoções são tidas como essenciais de forma a reforçar o entendimento delas como universais e naturais; a segunda e a terceira estratégias são similares, colocam em questão a universalidade das emoções, comparando os significados cambiantes das emoções de acordo com os contextos, seja de forma sincrônica ou diacrônica; a última estratégia, escolhida pelas autoras, é a de pensar as emoções como parte de um discurso emocional, como uma forma de ação social, indicando a importância de apreender como, por quem e onde as emoções podem e são atuadas e quais são os efeitos de poder nessas atuações. 
Rosaldo (1984) também aponta a importância de pensar as emoções não como privadas e naturais, opostas ao pensamento, mas como parte da cognição, atentando para seus significados na vida pública e para os padrões culturais que promovem modelos de ação humana e entendimento. A autora sugere que as emoções são processos melhor entendidos em referência aos roteiros culturais. Assim, nos roteiros dos júris as emoções, no caso a raiva e o ciúme, são aproximadas à violência, enquanto a própria decisão dos jurados, materializada na sentença, é apreendida como "técnica" e, portanto, não emocional. Contudo, é possível apontar deslizamentos como quando ao classificar o crime a DP diz "a realidade desse processo é triste, trágica e chocante, que é o que hoje é chamado de feminicídio": nessa fala, ela aproxima o "técnico", isto é, o processo, do emocional. Há um gerenciamento emocional (HOCHSCHILD, 2013) por parte da MP e DP, que evocam sentimentos determinados em cada momento dos júris, isto é, de forma situacional.

Myriam Jimeno (2004), antropóloga colombiana, foi uma das primeiras intelectuais a estudar o homicídio intra casais no livro Crimen passional: contribución a uma antropologia de las emociones. A principal tese apresentada é de que o crime passional é uma construção cultural. Para analisar tal fenômeno a autora parte da noção de "configuração emotiva" apresentada por Crapanzano (apud JIMENO, 2004), sendo o núcleo de tal configuração a pretensão da separação entre razão e emoção como polos apartados da experiência humana. Assim, categoria do senso comum, o "crime passional faz parte de um sistema mais amplo de concepção do sujeito moderno como aquele que cobiça o amor e a vida no parceiro como parte da identidade pessoal” (2002, p. 2).

Para a autora, assim como para outros estudiosos das emoções (LUTZ, 2012; COELHO; REZENDE, 2011; KATZ 2013) os atos de violência, como quaisquer outros, adquirem sentido em determinado contexto social e as emoções não devem ser interpretadas como o lado obscuro da humanidade, mas como parte integral do sistema cultural, sendo os sentimentos historicamente construídos e parte de um sistema de organização conceitual. Portanto, para Jimeno, os atos violentos são expressivos, no sentido de que suas significações estão para além da situação na qual ocorrem: está no próprio tecido social.

A autora entrevista um homem brasileiro preso por ter assassinado a namorada. Eles tinham um filho e uma relação de términos e retornos. Ele descobre que ela está o traindo vendo o amante pulando a cerca da casa, então a chama para jantar e a confronta. Ela nega tudo. Ele dá três tiros na namorada. Alega posteriormente que a amava demais e tinha ciúmes, além de ser viciado em cocaína e estar sob o efeito da substância durante o acontecido. $\mathrm{O}$ júri entende que o réu estava tomado pela paixão e não tinha capacidade de entender o que estava fazendo. Além do mais, soma-se a ideia de que o homicídio não foi realizado para obter proveito; fica o entendimento de que sob o efeito de suas paixões o homem não conseguiu se controlar (JIMENO, 2002, pp. 7-9).

Nas sociedades latino americanas, ainda segundo Jimeno, predomina a noção de pessoa como ser individual, com um eu interior, e a paixão aparece como uma expressão sentimental saída deste íntimo das emoções. O amor passional é entendido como uma névoa 
sob o juízo, como no caso citado pela autora. Assim, o passional é entendido como entidade separada do pensamento, com sua própria força e vontade. Por isso, o ato criminal vindo da paixão é visto como repentino e imprevisível. Mascarando as construções sociais envolvidas no ato, como por exemplo, o medo de ser traído ou o medo de ver a identidade diminuída pela traição do parceiro, e oculta a associação entre esses pensamentos e as crenças sobre os papéis sociais de homens e mulheres. No caso do júri apresentado há, contudo, uma diferença: a Defensoria no papel de defesa do réu indica que o acusado estaria arrependido por ter se deixado tomar pela raiva, mas que isso não é motivo para que o crime não lhe seja imputado.

Jimeno (2002) demonstra que tanto no Brasil quanto na Colômbia os crimes passionais são cometidos principalmente por homens, para a autora isso demonstrado que existem hierarquias de gênero presentes nessa ação. Culpar a paixão pelo ato violento é um processo de ocultamento dos sentimentos e pensamentos socialmente apreendidos que levam à violência.

Ainda segundo a autora, existe uma tradição cultural ocidental que associa o uso da violência com a explosão emocional. Essa tradição descansa na concepção das emoções como instintivas, incontroláveis, animalescas, concepção essa que está em consonância com a concepção de sujeito moderna como cindido entre razão e emoção. Se a emoção é irracional, a força que leva o indivíduo a usar a violência nos crimes de ódio, nos casos apresentados por Jimeno ira e ciúme diminuem a culpabilidade. No júri analisado neste artigo as figuras da MP e DP pedem que os jurados deixem suas emoções de lado, de forma a fazer justiça de uma maneira apresentada como racional.

O argumento principal da autora é que o crime passional é uma ação violenta que faz parte de uma determinada configuração emotiva. Em um esquema cultural que dissocia razão e emoção na psicologia humana, isso acaba por ocultar o modelamento social das emoções e as forças simbólicas e reais das relações de gênero. Jimeno não utiliza a palavra feminicídio, mas estuda assassinatos cometidos por homens contra (ex)companheiras, de forma a criticar justamente o entendimento de que seriam crimes "passionais" ${ }^{8}$. Da mesma forma, para Jimeno (2002) é preciso entender a vida emocional como resultado do ambiente sociocultural e como motivação para a ação dos indivíduos. Assim, as emoções fazem parte da estrutura social e de suas tensões de classe, gênero e etnia, sendo utilizadas para consagrar, legitimar ou excluir pessoas e categorias sociais.

Maria Claudia Coelho (2011) em conversa com Jack Katz (1988), a partir de uma perspectiva interacionista, entende que o autor formula a hipótese de que as atitudes das vítimas, nos casos dos assassinatos por ele analisados, foram interpretadas pelos agressores,

\footnotetext{
${ }^{8}$ Importante destacar que Jimento também estuda casos de mulheres que assassinaram seus (ex) companheiros, a autora demonstra que enquanto os homens recebiam penas menores por terem "perdido a razão" para a forte emoção, no caso das mulheres o contrário acontece, elas eram em geral consideradas frias e racionais - oposto ao seu estado "natural mais emocional" - e recebiam penas maiores.
} 
naquela situação, como um desafio a um "bem moral" essencial para o modo como se viam, provocando com isso uma espécie de "ira santa".

Assim, o autor apresenta exemplos: o bebê que não para de chorar desafia a autoridade paterna; o vizinho que obstrui a entrada da garagem ameaça o direito à propriedade; ou ainda o marido que queima os livros da esposa e atrapalha seus estudos desrespeita os direitos da mulher. Em todas essas cenas, Katz identifica uma dinâmica emocional que inicia com um sentimento de humilhação "holístico", ou seja, algo que toma conta do agressor e que coloca em xeque sua autoimagem, parecendo-lhe, naquele momento, ser eterno. A raiva decorreria da necessidade fundamental de salvaguardar essa autoimagem, funcionando assim como um "contraponto" da humilhação e motivando uma agressão que se, por um lado, não visa necessariamente à morte do agressor (podendo ser freada por uma mudança de atitude, como um pedido de desculpas, por exemplo), por outro, não se contenta com ela (podendo ter prosseguimento com a imposição de novas agressões ao corpo da vítima). Estaríamos assim diante de um complexo emocional humilhação-raiva, cuja lógica seria a defesa de certa moralidade percebida pelo agressor como essencial para sua identidade. (COELHO, 2010, p. 280-281).

Ainda segundo Coelho, o autor indica que é importante perceber que "a violência irrompe em situações que colocam em xeque algo que as pessoas envolvidas encaram, momentaneamente, como dimensões do Bem eterno" (KATZ apud COELHO, 2010). Seguindo essa sugestão, podemos entrever que, no caso do júri analisado, trata-se de uma visão tradicional do relacionamento e do dever sexual da esposa para o marido.

\section{Considerações finais}

Como anteriormente apontado, as emoções são mobilizadas nos júris como algo que poderia impedir a justiça, estando em contraponto ao argumento "técnico", que seria a figura da legislação da desistência voluntária. São também apresentadas como a resposta "natural" do júri, MP e DP, como cidadãos, em relação ao réu. Simultaneamente, as emoções humanizam as profissionais quando se dizem tristes ou chamam a "realidade do processo" de "trágica e chocante". Aparecem, por fim, como "motivo" para o crime, quando a DP menciona que o réu estaria arrependido por ter "se deixado levar pela raiva". Assim, por mais que haja um esforço constante para "afastar" as emoções do júri, elas são frequentemente mencionadas e performadas nas falas. Podemos pensar o contexto de expressão das emoções como o que dá a elas legitimidade: assim, na fala de Michele, quando ela chora ou quando descreve que sua filha teria deixado de ser uma criança doce, as emoções aparecem como legítimas. Em contraponto, a raiva impede que a "justiça seja feita" de forma adequada. Assim, há momentos nos quais as emoções aparecem positivamente ou negativamente, a depender da situação específica: a raiva, por exemplo, tem diferentes pesos para cada pessoa 
e em cada contexto. É possível pensar a importância das emoções na agência das pessoas nesses espaços, como uma linguagem performativa nos júris e não apenas como estados internos essenciais.

As emoções aparecem também relacionadas ao gênero (LUTZ, 1990), como quando Michele explicita que terminou seu relacionamento com o réu por ter aprendido a se amar "em primeiro lugar". O amor, a raiva e o ciúme aparecem nos discursos das representantes do Ministério Público e da Defensoria Pública. O gênero e as relações de gênero se fazem através dessas emoções (DIAZ-BENITEZ, 2019): o amor é associado à feminilidade, a raiva legítima é aquela sentida pela MP e pela DP em relação ao réu, ao mesmo tempo que o ciúme aparece como um sentimento que constrói a masculinidade do acusado e sua raiva como uma emoção que não justifica o crime. Atributos de feminilidade e masculinidade estereotípicos servem também para caracterizar vítima e réu. Assim, a qualificadora do feminicídio, ou seja, "o motivo do sexo feminino" segundo a lei, é definida no processo por ser o réu ex companheiro da vítima e pelo crime ter ocorrido na casa dela, configurando no processo "âmbito da violência doméstica", relacionando o feminino ao doméstico. Por outro lado, o final da relação de ambos, segundo Michele, perpassa o fato de Josué ser "mulherengo" e "ciumento"; contudo, depois de separado ele é qualificado como "bom pai". Os discursos sobre emoções versam também sobre gênero (LUTZ, 1990), estando o ciúme e a raiva atrelados a Josué no caso deste júri e nos casos estudados por Jimeno (2002).

Assim, podemos entrever algumas regras de sentimentos (HOCHSCHILD, 2013) nos júris, como a inadequação da raiva no momento de fazer justiça, ainda que seja uma resposta "adequada" aos casos ali apresentados, lidos como tragédias familiares; o amor próprio como justificativa para o fim de uma relação; e o ciúme e a raiva como insuficientes para justificar o crime, mas fazendo parte da descrição do ocorrido.

Ao longo do século XX os códigos penais latino americanos têm mudado. A ideia de emoção passional não é mais motivo para eximir alguém de um crime, ainda que possa aparecer como atenuante (JIMENO, 2002). Da mesma forma, a figura da honra não é mais central nesse tipo de julgamento, como era nos casos analisados por Corrêa (1983). As emoções são centrais neste júri e se configuram em sua rotina, nos cumprimentos e nas falas feitas pela MP e DP.

A partir do júri é possível também pensar a dinâmica mutuamente produtiva das relações entre gênero e Estado, seguindo as pistas dadas por Vianna e Lowenkron (2017). Esse júri como processo de produção e materialização do Estado (ABRAMS, 2006; MITCHELL, 2006) entrevê certas performances de gênero, como quando a representante do MP diz "aqui é o tribunal das mulheres", aproximando o Estado de uma representação feminina. Por outro lado, como demonstra Lutz (1990), as emoções são culturalmente aproximadas as mulheres enquanto a racionalidade é relacionada aos homens, assim, podemos ver uma representação masculina do Estado na ideia de que a justiça deve ser técnica em oposição à raiva que a MP sente pelo réu "como cidadã, esposa e mulher". 
A própria Lei do Feminicídio pode ser pensada como parte dessa dinâmica: fruto de uma reinvindicação feminista frente ao Estado, produz a estabilização de uma violência, feminicídio, como aquela violência perpetrada por (ex) companheiros contra parceiras, em ambiente doméstico. Assim, quando o processo contra o réu é classificado como feminicídio tendo como princípio a relação entre réu e vítimas ser uma antiga relação amorosa e de convivência doméstica. As leis específicas para mulheres ligam de maneira profunda gênero e Estado e a violência parece estar diretamente implicada nesse processo histórico desde as DDMs até a Lei do Feminicídio.

\section{Referências Bibliográficas}

ABRAMS, Philip. Notes on the difficulty of studying the State. In: Sharma, Aradhana; Gupta, Akhil, (Ed.). The anthropology of the state: a reader. Oxford: Blackwell, 2006.

ABU-LUGHOD, Lila; LUTZ, Catherine. Introduction. In: (Orgs.). Language and the

Politics of Emotion. Cambridge: Cambridge University Press, 1990. pp. 1-23.

CORREAA, Mariza. Morte em família. Rio de Janeiro: Graal, 1983.

COELHO, Maria Claudia; DURÃO Susana. Emoções, Política e Trabalho - estudos em antropologia das emoções. Interseções, v. 19, n. 1, pp. 40-60, 2017.

COELHO, Maria Claudia. Narrativas da violência: a dimensão micropolítica das emoções. Mana, v. 16, n. 2, pp. 265-280, 2010.

DEBERT, Guita Grin; GREGORI, Maria Filomena. Violência e gênero: novas propostas, velhos dilemas. Revista Brasileira de Ciências Sociais, v. 23, n. 66, pp. 165-185, 2008.

DIAZ-BENITEZ, María Elvira. O gênero da humilhação. Afetos, relações e complexos emocionais. Horizontes antropológicos, v. 54, pp. 51-78, 2019.

ELIAS, Norbert. O processo civilizador. Rio de Janeiro: Jorge Zahar Ed., vol 1, 1994.

GOODWIN, Jeff; JASPER, James M.; POLLETTA, Francesca (Orgs.). Passionate Politics emotions and social movements. Chicago: University of Chicago Press, 2001.

HOCHSCHILD, Arlie. Trabalho Emocional, Regras de Sentimento e Estrutura Social. In: COELHO, Maria Claudia (Org.). Estudos sobre Interação. Rio de Janeiro: EdUERJ, 2013.

JIMENO, Myriam. Crimen passional - contribución a una antropologia de las emociones. Cap. 2. Bogotá: Universidad Nacional de Colombia, 2004.

KATZ, Jack. Massacre Justo. In: COELHO, Maria Claudia (Org.). Estudos sobre Interação. Rio de Janeiro: EdUERJ, 2013.

LUTZ, Catherine. Engendered emotion: gender, power, and the rhetoric of emotional control in American discourse. In: LUTZ, Catherine; ABU-LUGHOD, Lila (Orgs.). Language and the Politics of Emotion. Cambridge: Cambridge University Press, 1990.

MAUSS, Marcel. A Expressão Obrigatória dos Sentimentos. In S. Figueira (Org.). Psicanálise e Ciências Sociais. Rio de Janeiro, Francisco Alves, 1980.

MITCHELL, Timothy. Society, Economy and the State Effect. In Sharma, Aradhana; Gupta, Akhil. (Eds.). The Anthropology of the State: a reader. MA, USA: Blackwell Publishing, 2006. pp.169-186. 
POSSES, Mariana Thortessen; OLIVEIRA, Clara Flores Seixas de. Política, direito e movimentos sociais: o caso da criação da lei do feminicídio no Brasil. 40 Encontro Anual da Aponcs. São Paulo, out. 2016.

RADFORD, Jill; RUSSELL, Diane (Org.). Femicide: the politics of woman killing. New York: Twayne Publishers, 1992.

REZENDE, Claudia Barcellos; COELHO, Maria Claudia. Antropologia das Emoções. Rio de Janeiro: Editora FGV, 2010.

ROSALDO, Michelle. Toward an Anthropology of Self and Feeling. In: Richard Shweder; Robert LeVine (Orgs.) Culture Theory: Essays on Mind, Self and Emotion. Cambridge: Cambridge University Press, 1984. pp. 137-57.

SHARMA, Aradhana; GUPTA, Akhil. Introduction: Rethinking theories of State in an Age of Globalization. In: (Ed). The anthropology of the state: A reader. Oxford: Blackwell, 2006. pp. 1-41.

SOUZA LIMA, Antonio Carlos de. O estudo antropológico das ações governamentais como parte dos processos de formação estatal. Revista de Antropologia v. 55, pp. 559-564, 2012.

VIANNA, Adriana; LOWENKRON, Laura. O duplo fazer do gênero e do Estado: interconexões, materialidades e linguages. Cadernos pagu, vol.49, 2017.

VIEIRA, Miriam Steffen. Categorias jurídicas e violência sexual: uma negociação com múltiplos atores. Porto Alegre: UFRGS, 2011.

\section{Brena O’Dwyer}

É doutoranda no Programa de Pós-Graduação em Antropologia Social no Museu Nacional/UFRJ, com mestrado em saúde coletiva pelo Instituto de Medicina Social da Universidade do Estado do Rio de Janeiro e pesquisadora associada ao Núcleo de Estudos em Corpos, Gênero e Sexualidade (NuSEX/PPGAS/MN/UFRJ). 